\title{
Assessment of Water Quality in the Molnár János Cave - Budapest, Hungary
}

\author{
Mariana Menoncin¹, Miklós Murai', Péter Szombathy¹, Dénes Szieberth* \\ ${ }^{1}$ Department of Inorganic and Analytical Chemistry, Budapest University of Technology and Economics, Múegyetem rakpart 3, \\ Budapest 1111, Hungary \\ * Corresponding author, e-mail: szieberth.denes@vbk.bme.hu
}

Received: 20 July 2021, Accepted: 30 August 2021, Published online: 05 January 2022

\begin{abstract}
Molnár János Cave (MJC) is the only underwater cave and the only active one in the Buda Thermal Karst system (BTK). At MJC, there is a large amount of water that can be considered as a possible source of drinking water. We evaluated the physical and chemical parameters of the cave water to understand natural and possible anthropogenic interference in water quality. Therefore, measurements of temperature and chemical compositions were performed for dripwaters and water from the cave conduits over a four-year period and compared to historical data. Statistical analysis of the produced data revealed yearly changes as well seasonal periodicity in the component ion concentrations. In the case of dripwaters, we observed a periodicity that revealed information about the origin of the dripwater. For the first time, we had identified seasonal variations in conduit waters. Previous studies only analyzed water at the entrance of the cave. Then, this research focuses on the water from the newly discovered inner passages.
\end{abstract}

Keywords

water chemistry, karst system, cave hydrology, seasonal and yearly periodicity

\section{Introduction}

Budapest is in the center of the Pannonian Basin. The Danube river divides the city, where Buda hills representthe westernmost part of the Transdanubian mountains. Under this mountain range lies Hungary's largest karst aquifer. The feet of the Buda hills act as a discharge zone of this aquifer, manifesting in a group of thermal springs near the Danube river. The sum of karst phenomena found in this area - including an extensive cave system of hypogenic origin - is named the Buda Thermal Karst (BTK) [1, 2]. The two main groups of active lukewarm springs, the Józsefhegy springs at Rózsa hill and the Gellért hill springs at Gellért hill make Budapest also famous for its baths [3, 4].

The evolutive processes in the BTK formed a groundwater flow inside the carbonate system. Channels were formed based on cracks and fractures caused by the tectonic evolution, which influences the groundwater migration and controls the dissolution and precipitation process $[5,6]$.

Rózsa hill is composed of Triassic dolomites, EoceneOligocene limestone, and marl. Waters at Rózsa hill discharge zone are lukewarm and hot springs. Cave morphology is multilevel complexes along the faults and bedding planes between the limestone and marl [7]. Multilevel cave systems are formed by the base level drop caused by the landscape evolution where the levels are younger when going downwards [8]. A water flow model from MádlSzönyi et al. [4] suggests that, at the site, there are mainly three flow systems. The first is the local flow system that involves the infiltration of surface water directly from the hillside; the second is the intermediate and regional flow systems from a larger region and mixed by free convection process; and third, the hydrothermal waters from below, rising from the base of the hill (Fig. 1).

At Rózsa hill, there are five known caves larger than $1 \mathrm{~km}$ each. MJC is an underwater cave located behind the discharge zone of lukewarm springs. This cave is under formation along with the fractures between the Eocene limestone and the Eocene-Oligocene marl. Following the same way as others, already dry caves, in the Rózsa hill [9].

MJC is one of the largest active submerged hydrothermal caves in the world. The cave is an example of a hypogenic cave, formed by ascending waters with no surface interference. The cave is still under formation by mixing corrosion, caused by the mixture of different calcite saturated waters with different temperatures and ion content [9-12]. 


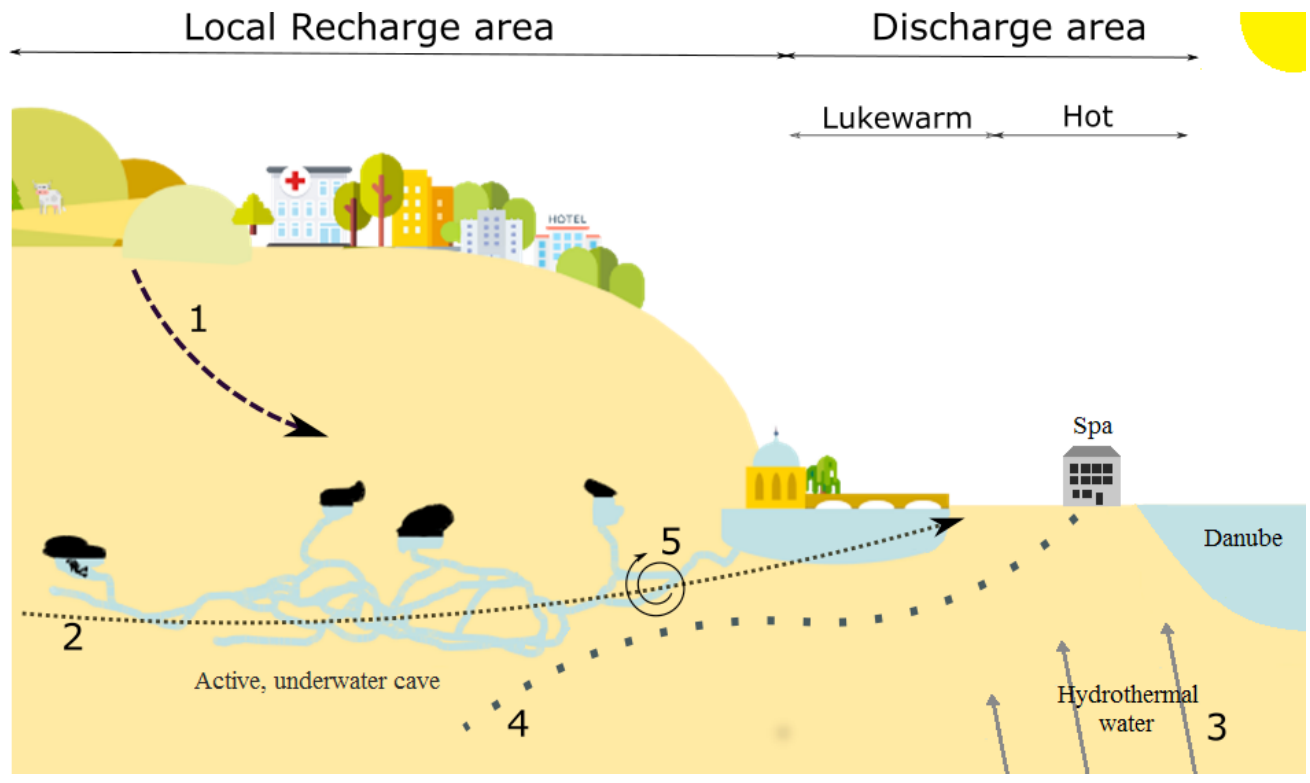

Fig. 1 Model of discharge at Rózsa Hill. Where: 1: local flow; 2: intermediate flow; 3: regional flow; 4: supposed mixing zone; 5: free convection (based on Mádl-Szőnyi et al. [4])

\subsection{Historical background of MJC and characterization of the studied area}

At the foot of Rózsa hill, two springs discharge water into a dam lake called the Malom lake (ML). The lukewarm waters of these springs have originally been used by a water mill and are utilized by public baths for centuries. In the 1860 s a study about these springs water chemistry was published and the existence of an underwater cave feeding the springs was concluded [13]. The chemical composition and the temperature of the two springs were found to be different $\left(27\right.$ and $29^{\circ} \mathrm{C}$ ). Further studies from 1980 s noted a decrease in temperature of these springs to $21.8^{\circ} \mathrm{C}$ and $23.8^{\circ} \mathrm{C}$ [14].

By draining the lake temporarily, cave passages leading under the Rózsa hill were discovered. From the 1960's, cavers and cave divers gradually explored an approximately $600 \mathrm{~m}$ long passage system with a maximum depth of $35 \mathrm{~m}$.

Inside the cave, while the parts deeper than $10 \mathrm{~m}$ had a constant temperature of $20.5{ }^{\circ} \mathrm{C}$. Upper passages displayed a fluctuating temperature a passage found at $8 \mathrm{~m}$ depth contained warmer water $\left(25.3^{\circ} \mathrm{C}\right)$.

In 2002, after breaking through a small opening - where warmer water and silt was entering the passage - divers found the continuation of the cave, leading to the discovery of several kilometers of new passages. The Kessler hall $(\mathrm{KH})$ was discovered. This hall displays a cave lake with a diameter of $20 \mathrm{~m}$ and ceiling height of $10 \mathrm{~m}$ above the water level [5]. In 2008, after drilling a new tunnel that connected the KH with a nearby drift, KH lake became the starting point of the cave [15].
As of now, the MJC is a large cave with a maze-like structure extending several kilometers. Characterization of the cave is impossible with only those few sampling points that are accessible from the surface. The flow system of the passages near the ML was completely rearranged after the opening of the passage leading to the new parts, consequently, some of the earlier observations about the submerged passages may not be comparable to the newer results.

Several recent studies also show the average temperature of one of the springs, called Boltiv spring, and the ML. According to Eröss et al. [16] and Farkas et al. [17] the average temperature of the ML varies between 21.5 and $23{ }^{\circ} \mathrm{C}$ and the temperature of the Boltív spring varies from 21.4 to $21.7^{\circ} \mathrm{C}$. This temperature fits among the other lukewarm springs found at the foot of Rózsa hill. Where, lukewarm waters vary from 20 to $37^{\circ} \mathrm{C}$ and hot springs, normally from 40 to $65{ }^{\circ} \mathrm{C}[18,19]$.

The temperature of the water in the $\mathrm{KH}$ was observed to be different in two distinct layers. According to Eröss et al. [5] near the water table, the temperature is approximately $24{ }^{\circ} \mathrm{C}$ and $19{ }^{\circ} \mathrm{C}$ in $30 \mathrm{~m}$ depth. The Farkas et al. [17] study mentions that under the $\mathrm{KH}$ the temperature of the water layer shallower than $10 \mathrm{~m}$ are approximately $27{ }^{\circ} \mathrm{C}$ while the deeper waters are $21^{\circ} \mathrm{C}$. In addition, the upper layer shows a small change depending on the season. From November to January the average was $27.3{ }^{\circ} \mathrm{C}$, from January to March it was $26.6^{\circ} \mathrm{C}$ and from September to October, it was $27.5^{\circ} \mathrm{C}$. 
The first papers describing the water chemistry of the newly discovered passages are from Erőss et al. [16] and Bergmann et al. [20]. The sampling however was restricted to the parts of the cave accessible from the surface. Generally, the lukewarm waters of the Rose hill as $\mathrm{Ca}-\mathrm{Na}$ and $\mathrm{HCO}_{3}-\mathrm{Cl}-\mathrm{SO}_{4}$ facies type. The cave is divided into two (outer and inner) parts: The inner is characterized by higher $\mathrm{Ca}^{2+}(120 \mathrm{vs} 108 \mathrm{mg} / \mathrm{l})$ and $\mathrm{HCO}^{3-}$ (465 vs $416 \mathrm{mg} / \mathrm{l})$ concentrations. The inner sampling point is not specified in the paper, but presumably, it is the KH [19]. Bergmann et al. [20] sampled the KH, Dexion branch (a passage connected to the ML and one spring) and the ML. Several ion concentrations were recorded monthly from May 2009 to January 2011.

Farkas et al. [17] also published chemistry data both about ML and the KH. The published average of 6 sampling campaigns in 2014 gives a slight but significant (between 5 and 10\%) increase in the hydrogen carbonate and calcium ion concentrations. Also, a similar decrease in the sulfate ion concentration compared to the results of Bergmann et al. [20]. The sodium ion concentrations show more than double figures and that - in the absence of a comparable change in the counterions - is probably a measurement artefact in one of the studies, not a natural phenomenon. Both studies agree that the passage filling waters of the cave are very clean, conforming to drinking water regulations.

Apart from the water filling the cave passages, the chemistry of the dripwaters reaching the air-filled parts of the cave was also recorded to assess the vulnerability of the cave to anthropogenic contamination [17, 20]. Dripwaters belong to different water facies, containing lower hydrogen carbonate and very high sulfate concentrations indicating that the flow path of the dripping water leads through the upper pyrite containing Buda marl layers [20]. High nitrate concentrations and the relatively large fluctuations in time reflect the effect of surface precipitation and anthropogenic pollution.

Since a detailed description of the chemistry of the waters filling the submerged passages of the cave beyond the $\mathrm{KH}$ is missing from the international literature, our study aims first at the characterization of water chemistry in these passages, identifying the different inflows that contribute to the recharge of the cave. Our secondary aim is to investigate the incidental seasonal changes both in the passage filling waters and in the dripwaters infiltrating the cave that carry anthropogenic pollution. This task was made possible by the regular sampling executed by cave divers in the four years period from 2016 to 2019. About 183 water samples were collected and analyzed. 77 of the samples were from the submerged parts of the cave, collected with the help of cave diving techniques.

Our study builds on and continues the study published in 2015 by our research group (Farkas et al. [17]).

\section{Methods}

\subsection{Sampling and laboratory analysis}

PET bottles were used to collect cave water samples. In the case of underwater samples, cave diving techniques were used to reach the sampling sites (Fig. 2). After surfacing, conductivity and $\mathrm{pH}$ was measured with handheld instruments (Voltcraft WA-100 ATC 3\% 0-1999 $\mu$ S and pH -100 ATC $0.2 \mathrm{pH} 0-14)$. When the equipment and personnel were available in the cave, hydrogen carbonate content was also determined on-site by titration with $\mathrm{HCl}$, then the samples were transferred to the laboratory for further analysis.

Sulfate, hydrogen carbonate, chloride, calcium, magnesium, and sodium ion concentrations were analyzed, as the previous studies indicated that these are the main dissolved components. Nitrate concentration was also determined as the most related pollution indicator. Samples were tested for phosphate, ammonium and nitrite ions as well, however, no detectable amount of these ions were present. The obtained concentrations are collected in a table in Section 3.2.

Laboratory analyses were carried out according to the recommendations of the Hungarian National Standards MSZ-448 [21]. Calcium and magnesium ions were determined by complexometric titration. For the determination of chloride ions, the Mohr method was used. Nitrate ions were determined spectrophotometrically by the nitration of salicylic acid. For sulfate determination, the turbidimetric method was used. Sodium and potassium were determined with atomic emission spectroscopy (AES).

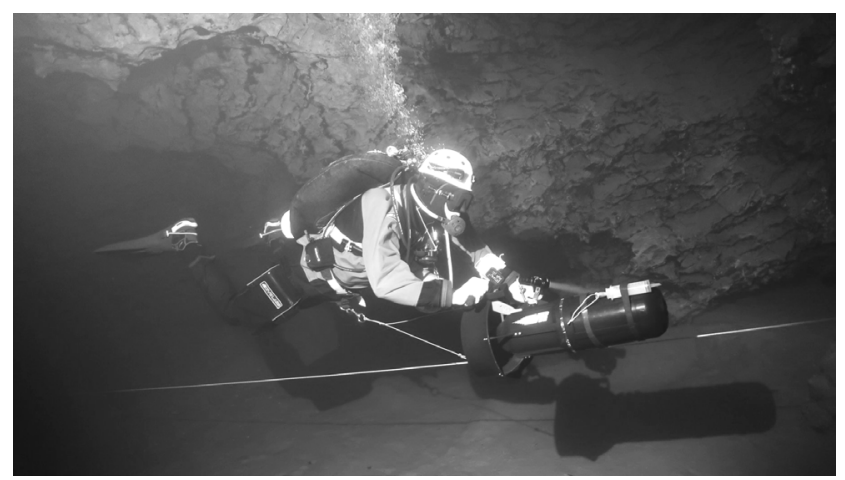

Fig. 2 Photo of a sampling point inside the cave conduits 
For the temperature, eleven glass thermometers with $0.2{ }^{\circ} \mathrm{C}$ scale division housed in protective Plexi tubes were placed at fixed positions (T1 to T11) (indicated on the map displayed in Fig. 3). Divers passing these points during tourist dives read the thermometers and recorded the value on the slate during 2016 and 2017 with approximately 2 months frequency.

The initial selection of water sampling points was determined along with the considerations: sampling points should cover the largest possible variety with respect to location, size of the passage, observable flow, and temperature - within the safe diving limits of the research diver's training and equipment. Sampling points where regular sampling was not possible and did not show significant difference in characteristics to nearby points were dropped or merged. Sampling was discontinued in the ML because the mixing of the spring waters is not complete at any point. Locations of the 13 selected sampling sites are marked in Fig. 3.

With the aim to settle the similar sampling points into groups, cluster analysis was performed using the before mentioned physical and chemical parameters for the sampling points.

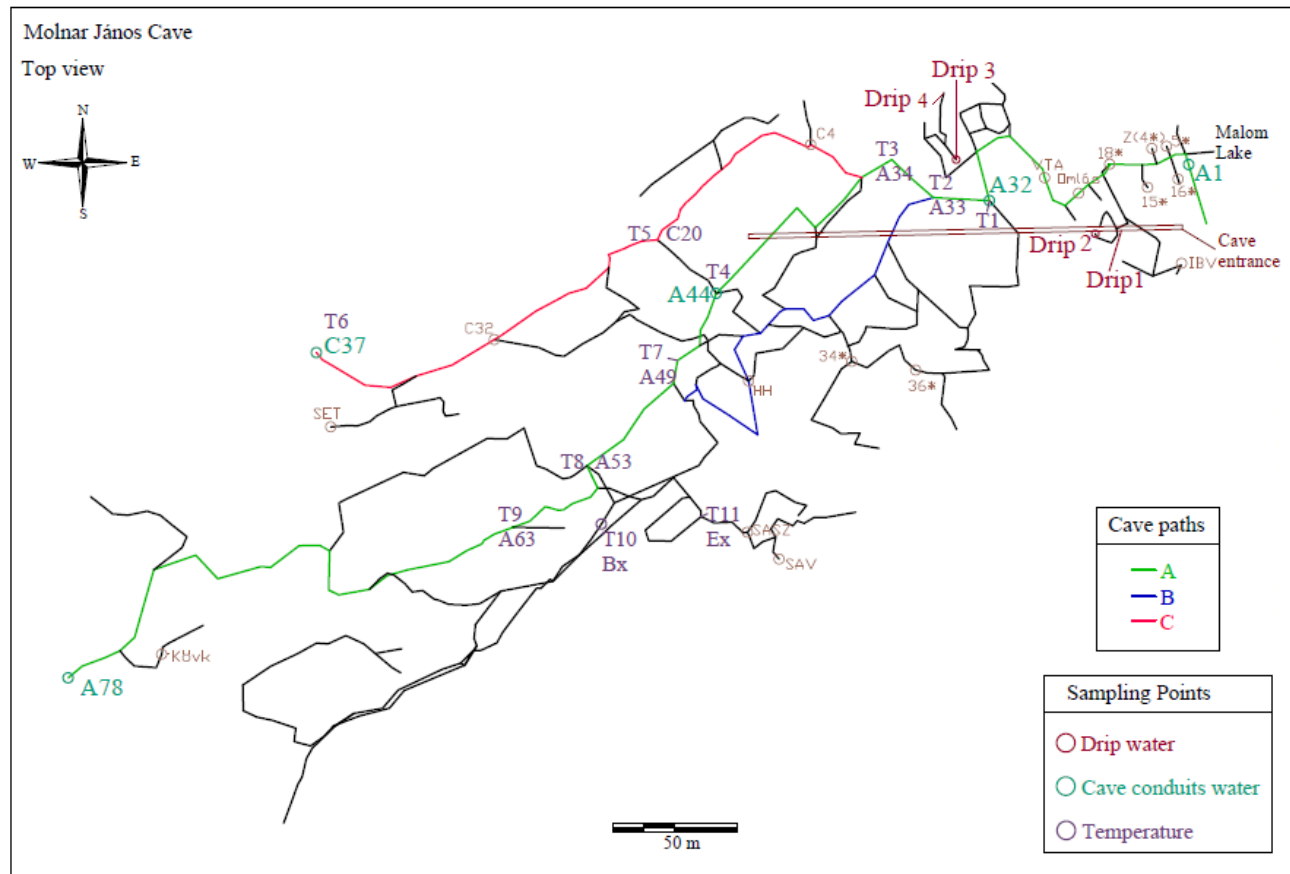

(a)

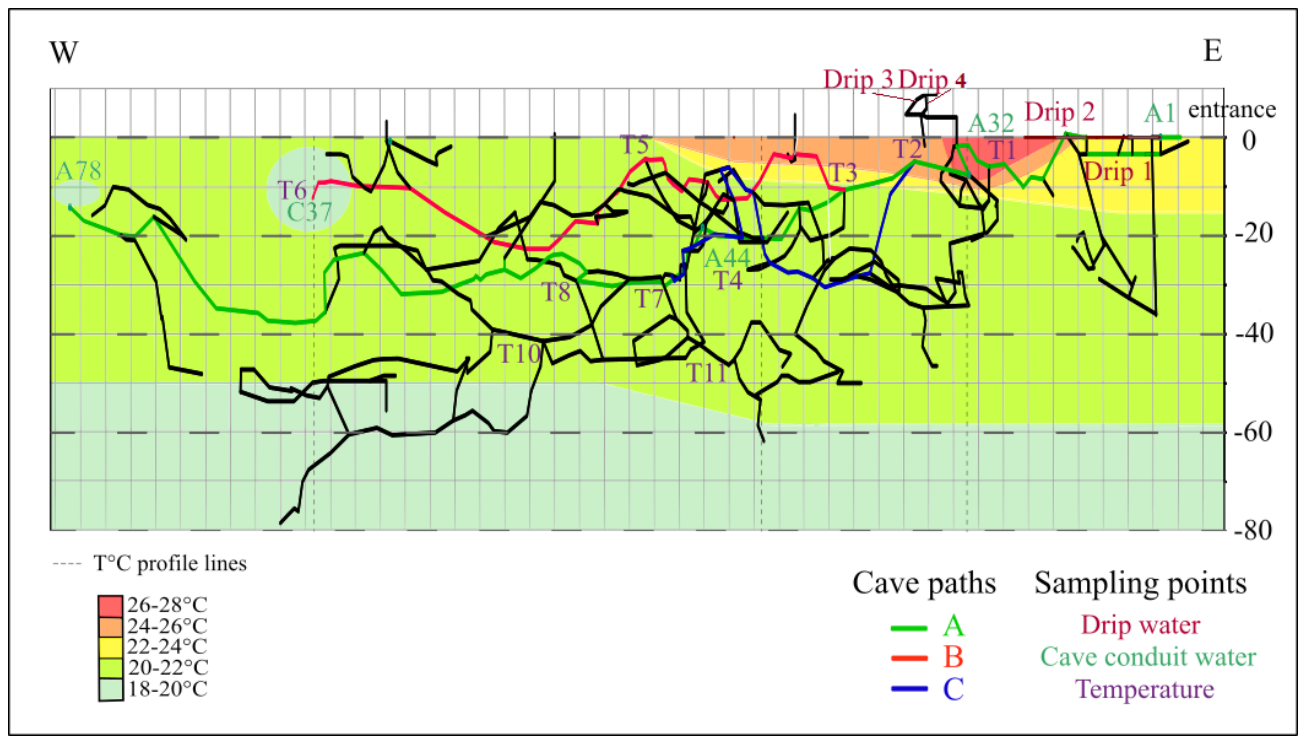

(b)

Fig. 3 Sampling points at MJC (a) top view (b) side view and temperature map 
In the following, we provide a short description of the location of the sampling sites.

\subsubsection{Dripwater collecting sites}

Although 8 air-filled chambers are known at various sites in the cave, dripwater is only detected close to the entrance and the $\mathrm{KH}$. The innermost drip site is observed above the $\mathrm{C} 4$ point, the very recent discovery and the difficult approach however allowed no sample in the presented sampling period.

Drip1 is the intersection point of the drift leading to the cave and a crack zone. Directly under the drip zone are shallow passages of the cave, forming a possible pollution site.

Drip2 is very close (about $5 \mathrm{~m}$ ) to Drip1, at the end of a short side-tunnel of the drift. The dripwater flows on the rock wall closing the tunnel, leaving a layer of flowstone. Sampling site began only in 2018, since the side tunnel was used earlier for storing equipment, and the flowstone formation was not discovered earlier.

Drip3 collects the water infiltrating through the ceiling of the KH. The ceiling is bisected approximately in the middle with a chert seam where the dripping is the most intense. Dripwater is collected at the opposite side to the entrance, where a short dry passage gives us the possibility to place the collecting equipment.

Drip4 is located at the end of a narrow lake separated from the $\mathrm{KH}$ by a rock pile approx. $5 \mathrm{~m}$ high. The place is also called a "waterfall" since the water continuously trickles down on one of the walls, occasionally with higher (estimated $10 \mathrm{l} / \mathrm{min}$ ) yield. Under the trickle a flowstone formation can be observed.

Waters from the submerged passages: A1: This site samples a spring, one of the two outlets of the cave a few meters before it flows into the ML. The samples are taken from the surface of the water.

A32: the KH displays the largest lake of the MJC that is accessible to non-divers, also the only one that contains breathable air. The temperature of the water is also the highest in the cave.

A44: a large hall located at the crossing point of two major passages, about $300 \mathrm{~m}$ from the $\mathrm{KH}$ in the $\mathrm{SW}$ direction, towards inside of the hill.

A78: The farthest point of the "A" passage, approximately $500 \mathrm{~m}$ from the $\mathrm{KH}$, near to the ceiling of the largest known hall of the cave, that vertically spans from the floor at $45 \mathrm{~m}$ to the ceiling at $15 \mathrm{~m}$. Close to this point at the end of a side tunnel, a cold-water inflow is detected, reportedly even colder in temperature $\left(16.5^{\circ} \mathrm{C}\right)$ than the
C37 point, however the cumbersome approach did not allow regular sampling of the cold inflow.

C37: Colder water inflow at the endpoint of the $C$ passage. According to the map, this place is directly below the Children's Hospital of Buda, in case of direct contact to the surface through fissures specific micro-contaminants can be expected.

\subsection{Data analysis and mapping}

Cave divers secure the explored passages by fixing guidelines so that they can find the exit even in zero visibility. These guidelines also form the base for cave mapping. For every straight stretch of the guideline, the direction and length are measured as well as the depth of the endpoints, forming a 3D line map (Fig. 3). In the MJC the largest passages are marked with the letters A-E, and the direction changes are numbered from the starting point, e.g., the $14^{\text {th }}$ breaking point on the A passage is marked with A14. These markings are used to identify the sampling points as well. The most comprehensive map of the MJC was produced in 2014 by its cave research team [17]. Although new surveys were carried out and some parts of the guideline system were modified since 2014, we use that version as the most complete one.

The collected data were subjected to multivariate analysis, focusing on the statistical approach for pattern recognition purposes. Cluster analysis represents a profile of possible different groups, based on similarities. The principle of this method is based on the means of distance [22]. Hierarchical cluster analysis was applied using Ward's method and set by squared Euclidean distance in the NCSS 2021 statistical software.

To interpret possible seasonal interference, the data was sorted by four seasons. March to May, June to August, September to November and December to February. The average, standard deviation (SD) and coefficient of variation $(\mathrm{CV})$ are used to analyze the data. $\mathrm{CV}$ is the ratio of the standard deviation to the mean. The higher the coefficient of variation, the greater the level of dispersion is around the mean. Results are precise when the value of CV is small. For analytical measurements, CV should be less than $10 \%$, while larger CV represents seasonality.

\section{Results and discussion}

\subsection{Temperature}

Considering the accuracy of reading the small scales underwater, we can conclude that the temperature of the observed locations did not change during the 2 years, the only 
observable temperature changes are caused by the vertical movements of the thermoclines. Average values measured with the fixed thermometers are displayed in Table 1.

Temperature profiles of the cave passages were also recorded by divers carrying a custom-made data logger, consisting of a pt100 sensor housed in a thin-walled metal tube for fast settling time connected to an Arduino-based data logger. At places where large depth differences could be spanned in a short horizontal distance, vertical temperature profiles were also recorded (marked as dotted lines in Fig. 3 (b)). Outstanding values were double-checked with repeated measurements. Collating the temperature profiles and the recorded values at the fixed points we have created a conceptual temperature map of the cave shown in Fig. 3 (b).

The hottest part of the cave is the immediate vicinity of $\mathrm{KH}$. At this location, the upper $9 \mathrm{~m}$ layer of the water is uniformly $27.8^{\circ} \mathrm{C}$. After a relatively sharp thermocline of approximately $2 \mathrm{~m}$ thickness the temperature drops to $21.0{ }^{\circ} \mathrm{C}$ and remains above $20.5{ }^{\circ} \mathrm{C}$ down to approximately $40 \mathrm{~m}$. The temperature of the warmer upper layer decreases with the distance from the $\mathrm{KH}$ (both towards the inner and outer parts of the cave), after the A44, B12 and C23 points the temperature difference between the deeper and shallower layers disappear, the approximately $21{ }^{\circ} \mathrm{C}$ water occupies the shallow passages as well. The temperature maximum at the $\mathrm{KH}$ indicates that the upwelling of the thermal water is near this spot, however, repeated extensive search by divers could not locate the inflow.

Below $40 \mathrm{~m}$ the temperature gradually decreases, deeper than $50 \mathrm{~m}$ the temperature sinks below $18^{\circ} \mathrm{C}$, except for the vertical closest to the $\mathrm{T} 1$, where even at the deepest point $(61 \mathrm{~m})$ the temperature stayed the same as above $40 \mathrm{~m}$. With the exceptions of the mixing zones, no temperature variations were observed in time.

A temperature anomaly appears at $\mathrm{C} 37$. The $\mathrm{C}$ passage forms a small hall at this point, the bottom $1 \mathrm{~m}$ of the hall is filled with colder water. The colder water flows from a restriction at the end of the hall that makes the further exploration of the passage problematic. A similar anomaly is present near to the end point of the A passage (A78).

Table 1 Temperature and depth of sampled points

\begin{tabular}{lcccccc}
\hline & A32 & A33 & A35 & A44 & C20 & C37 \\
\hline Depth [m] & 6 & 9 & 12 & 22 & 9 & 14 \\
Temperature $\left[{ }^{\circ} \mathrm{C}\right]$ & 27.7 & 26.3 & 21.0 & 20.9 & 26.5 & 18.5 \\
& A49 & A53 & A63 & Dx & Ex & \\
\hline Depth [m] & 35 & 32 & 28 & 38 & 37 & \\
Temperature $\left[{ }^{\circ} \mathrm{C}\right]$ & 20.6 & 20.7 & 20.6 & 20.9 & 21.1 & \\
\hline
\end{tabular}

The inflow of significantly colder water indicates a shallower flow path that might carry pollution from the surface.

\subsection{Water chemistry analysis}

Two different main groups were identified (see Fig. 4), exactly mirroring the main different water sources: dripwaters from the ceiling of the dry passages (group 1) and waters filling the submerged passages (group 2).

After further clustering of the sampling sites, the number of sampling points was reduced: points A53, A63, Ex, Dx were dropped in favor of A44, the most easily accessible site from this group. Indeed, the concentrations measured at these sites were within the standard variation to the concentrations measured at A44. Site C20 was dropped because it looked like a mixture from A44 and A32, no extra component was detected at this site. The shortlist of sampling points selected for regular sampling is collected in Table 2.

The temperature differences reflect the differences in water chemistry: the distance of the sampling points based on the chemistry data resulted in the same groups as shown by the temperature. The average concentrations for the entire sampling period are found in Table 3.

The chemistry of each sampling point is visualized with the help of radar graphs (Fig. 5). The most obvious difference is between the dripwaters and the conduit waters that agrees with the results of the cluster analysis. Radar graphs within the same group have a similar shape, while the graphs of the two groups are different.

Sulfate concentrations are multiple times higher in the dripwaters than conduit waters, also nitrate, chloride, sodium, magnesium, and calcium have higher

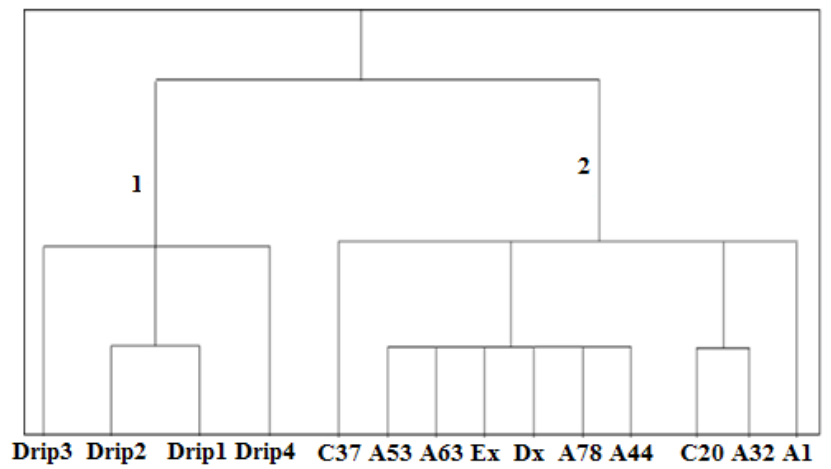

Fig. 4 Cluster analysis

Table 2 Selected sampling points depth and water temperature

\begin{tabular}{lccccc}
\hline Sampling site & A1 & A32 & A44 & A78 & C37 \\
\hline Depth $(\mathrm{m})$ & 0 & 0 & 21 & 15 & 14 \\
Water temperature $\left({ }^{\circ} \mathrm{C}\right)$ & 23.0 & 27.8 & 20.9 & 20.9 & 18.5 \\
\hline
\end{tabular}


Table 3 Water chemical composition in MJC

\begin{tabular}{|c|c|c|c|c|c|c|c|c|c|c|}
\hline & n.s. ${ }^{\mathrm{c}}$ & $\begin{array}{c}\text { Cl- } \\
(\mathrm{mg} / \mathrm{l})\end{array}$ & $\begin{array}{l}\mathrm{SO}_{4}^{2-} \\
(\mathrm{mg} / \mathrm{l})\end{array}$ & $\begin{array}{l}\mathrm{NO}_{3^{-}} \\
(\mathrm{mg} / \mathrm{l})\end{array}$ & $\begin{array}{l}\mathrm{HCO}_{3^{-}} \\
(\mathrm{mg} / \mathrm{l})\end{array}$ & $\begin{array}{c}\mathrm{Na}^{+} \\
(\mathrm{mg} / \mathrm{l})\end{array}$ & $\begin{array}{c}\mathrm{K}^{+} \\
(\mathrm{mg} / \mathrm{l})\end{array}$ & $\begin{array}{c}\mathrm{Ca}^{2+} \\
(\mathrm{mg} / \mathrm{l})\end{array}$ & $\begin{array}{l}\mathrm{Mg}^{2+} \\
(\mathrm{mg} / \mathrm{l})\end{array}$ & \\
\hline \multirow[t]{3}{*}{ Drip1 } & Mean & & 186 & 494 & 88.0 & 131 & 67.0 & 5.1 & 164.3 & 83.5 \\
\hline & S.D. ${ }^{d}$ & 34 & 12 & 52 & 12 & 38 & 1.9 & 0.7 & 9.5 & 7.8 \\
\hline & C.V. ${ }^{\mathrm{e}}(\%)$ & & 7 & 10 & 13 & 29 & 2.8 & 14.0 & 5.8 & 9.4 \\
\hline \multirow[t]{3}{*}{ Drip2 } & Mean & & 202 & 609 & 84.0 & 288 & $\ldots$ & $\ldots$ & 257.9 & 123.4 \\
\hline & S.D. ${ }^{d}$ & 12 & 27 & 17 & 21.7 & $\ldots$ & $\ldots$ & $\ldots$ & 15.5 & 4.5 \\
\hline & C.V. ${ }^{\mathrm{e}}(\%)$ & & 13 & 3 & 25.8 & $\ldots$ & $\ldots$ & $\ldots$ & 6.0 & 3.6 \\
\hline \multirow[t]{3}{*}{ Drip3 } & Mean & & 203 & 825 & 49.0 & 130 & 81 & 5.9 & 264.0 & 162.5 \\
\hline & S.D. ${ }^{d}$ & 29 & 9 & 42 & 5.4 & 36 & 6.7 & 0.3 & 18.0 & 44.8 \\
\hline & C.V. ${ }^{\mathrm{e}}(\%)$ & & 5 & 5 & 11.1 & 27 & 8.3 & 5.0 & 6.9 & 27.6 \\
\hline \multirow[t]{3}{*}{ A1 } & Mean & & 48 & 133 & 7.4 & 378 & 24.4 & 3.7 & 119.7 & 43.9 \\
\hline & S.D. ${ }^{d}$ & 8 & 3 & 5 & 0.4 & 5 & 0.2 & 0.0 & 1.2 & 0.7 \\
\hline & C.V. ${ }^{\mathrm{e}}(\%)$ & & 7 & 3 & 5.0 & 1 & 0.7 & 1.3 & 1.0 & 1.7 \\
\hline \multirow[t]{3}{*}{ A32 } & Mean & & 69 & 142 & 5.9 & 431 & 47.7 & 6.0 & 128.7 & 45.0 \\
\hline & S.D. ${ }^{d}$ & 23 & 5 & 15 & 0.6 & 43 & 1.1 & 0.1 & 6.6 & 4.1 \\
\hline & C.V. ${ }^{\mathrm{e}}(\%)$ & & 7 & 10 & 11.0 & 10 & 2.2 & 1.7 & 5.1 & 9.3 \\
\hline \multirow[t]{3}{*}{ A44 } & Mean & & 44 & 120 & 8.0 & 378 & 22.5 & 3.3 & 115.1 & 46.7 \\
\hline & S.D. ${ }^{d}$ & 17 & 2.7 & 9 & 0.8 & 11 & 0.7 & 0.2 & 4.0 & 1.9 \\
\hline & C.V. ${ }^{\mathrm{e}}(\%)$ & & 6 & 8 & 9.5 & 3 & 3.3 & 5.3 & 3.5 & 4.1 \\
\hline \multirow[t]{3}{*}{ A78 } & Mean & & 44 & 137 & 8.0 & 368 & 20.2 & 3.0 & 109.9 & 46.0 \\
\hline & S.D.d & 9 & 2 & 5 & 1.1 & 6 & 1.3 & 0.3 & 11.2 & 3.5 \\
\hline & C.V. ${ }^{\mathrm{e}}(\%)$ & & 5 & 3 & 13.9 & 2 & 6.4 & 8.7 & 10.2 & 7.6 \\
\hline \multirow[t]{3}{*}{ C37 } & Mean & & 44 & 123 & 9.7 & 356 & 19.2 & 2.9 & 109.9 & 47.4 \\
\hline & S.D. ${ }^{d}$ & 13 & 3 & 5 & 1.0 & 7 & 0.8 & 0.3 & 10.6 & 5.9 \\
\hline & C.V. ${ }^{\mathrm{e}}(\%)$ & & 6 & 4 & 9.8 & 2 & 4.1 & 8.7 & 9.6 & 12.5 \\
\hline
\end{tabular}

Note: average values of the entire 4 years sampling period and overall coefficient of variation;

${ }^{\mathrm{c}}$ Number of samples analyzed; ${ }^{\mathrm{d}}$ Standard deviation; ${ }^{\mathrm{e}}$ Coefficient of variance

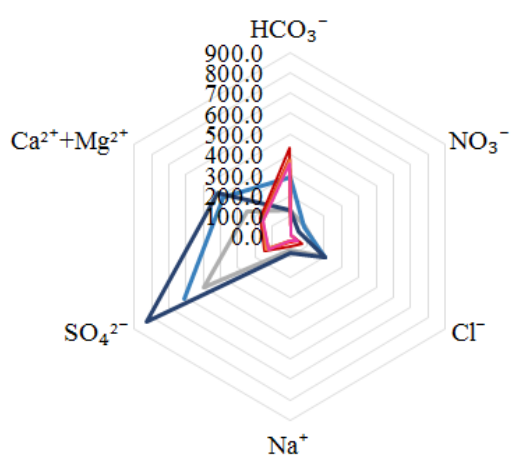

-Drip 1 -Drip 2 -Drip $3-\mathrm{A} 1$-A32 -A44 - A78 - C37

Fig. 5 Radar graph for ion concentrations (mg/l)

concentrations than conduit waters. Hydrogen carbonate follows the opposite trend, it is higher in conduit waters than in dripwaters. These results agree with Farkas et al. [17].

In the case of dripwaters, direct comparison with earlier results can only be made with the paper from Farkas et al. [17], because the exact sampling points could not be determined in earlier studies. The Drip3 sampling point in the present study is identical to the $\mathrm{K} 1$ in
Farkas et al. [17], while Drip1 corresponds to T2. The average of concentrations from 2016-2019 and the ones from 2011 and 2015 are compared in Fig. 6.

The main characteristics of the dripwaters remained the same: in both samples, the most abundant anions are the sulfate, and the chloride, however hydrogen carbonate and nitrate were also found. Calcium and magnesium are the highest concentration cations with large sodium content as well. Although the high nitrate and chloride content indicates pollution from the surface, the extremely high sulfate suggests a long residence time in the pyrite containing marl layers that are situated above the level of the cave. The long residence time agrees with the lack of ammonium, nitrite (depleted by oxidation) and phosphate (adsorption), and with the apparent lack of short-range correlation of rainfall with the drip rates [17].

In case of Drip1, magnesium, nitrate and sodium concentrations decrease, while hydrogen carbonate increases. We consider larger than 5\% change in the concentrations as significant. Chloride, sulfate, and calcium concentrations do 


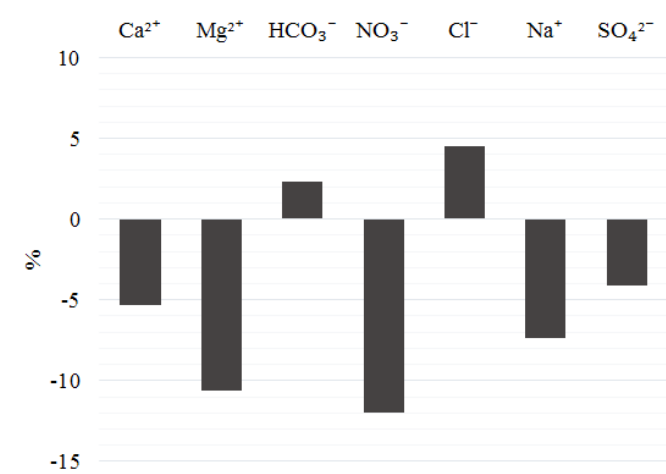

(a)

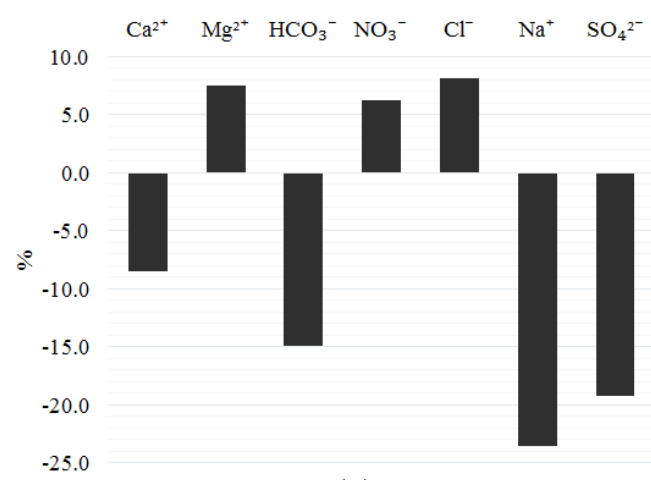

(c)

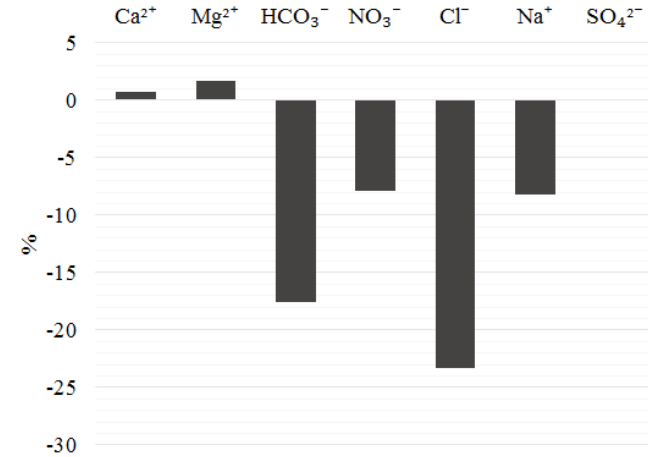

(b)

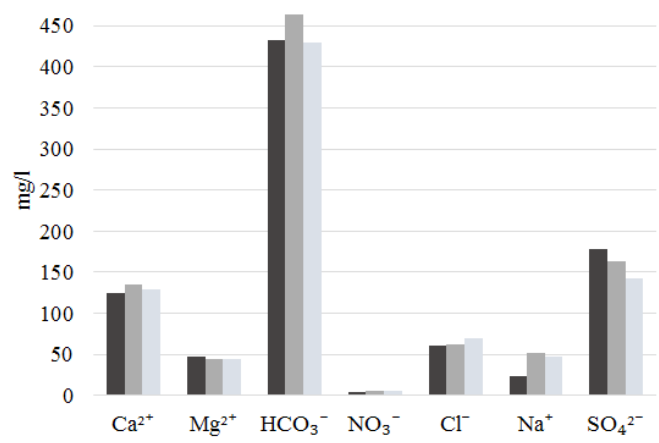

- Bergmann (2011)[20] $\backsim$ Farkas (2015)[17] $\backsim$ A32 (2016-2019)

(d)

Fig. 6 Comparison of data with past results (a) percentage difference between Drip 1 and [17], (b) percentage difference between Drip 3 and [17],

(c) percentage difference between 37 and [17] and (d) concentration comparison (mg/l) between A32 [17, 20]

not display notable changes. The most significant difference is the decrease of nitrate concentrations, which, since nitrate ions have no other source apart from the surface, suggests the diminishing use of fertilizers at the infiltration site or the repair of the sewers in the area. The $10 \%$ decrease in the $\mathrm{Mg}$ content that is accompanied by a $5 \%$ decrease in $\mathrm{Ca}$ (and then subsequently changing $\mathrm{Ca}: \mathrm{Mg}$ ratio) might indicate a shorter residence time of the dripwater in the carbonate rocks. The decreasing $\mathrm{Na}+$ content without the corresponding decrease in chloride might also be the result of a shortened contact, so less ion exchange with clay minerals.

Drip3 also displays changes compared to the data obtained in the 2014 sampling periods, however, both the affected ions and the direction of the change are different. The largest differences are the decrease of hydrogen carbonate and the parallel decrease of the nitrate, chloride, and sodium content. The large decrease of the chloride and sodium concentrations might be the result of the gradual switch to environmentally friendly de-icing agents as calcium magnesium acetate (CMA).

The Drip4 site was not sampled in the 2015 study, so comparison can only be made with the Bergmann et al. [20] paper. Both studies observed very high variation in the measured concentrations. Our 4-year average show a significant decrease in all measured ion concentrations compared to 2010, however the number of samples (total of 6 in 4 years, since the research permit of the divers did not allow them to pass dry stretches in the cave) did not provide for good averaging.

In the present work, two drip sites were dropped from the ones sampled in the Farkas et al. [17] study (T1 and T3), because of lab capacity issues, but two additional sites (Drip2, Drip4) were also included in the sampling. On these sites -unlike the other sites- a layer of flowstone formed under the dripping, indicating a difference in the chemistry. Also, Drip4 carries the largest volume of dripwater into the cave.

In principle the differing location of the dripwater sampling sites allows us to draw conclusions about the correlation between the distance from the entrance or the vertical travel path and the chemistry of the dripwaters. However, Drip1 and Drip2 are very close to each other and have a quite different composition. This observation warns us that the individual dripping sites may have separate infiltration paths, not necessarily related to the surface located above the sites. 
The buffering effect of a detrital zone in the epikarst can also modify the concentrations in another way for the different infiltration paths.

Comparing the very closely located Drip1 and Drip2 sites, we can observe that the concentration of calcium, magnesium and hydrogen carbonate ions are significantly lower in the Drip2 samples (Fig. 7). Since these ions come from the speleothems observable elsewhere in the cave (flowstones, gypsum crystals), we may attribute these differences to PCP (prior calcite precipitation). Since calcite precipitation requires a drop in $\mathrm{pCO}_{2}$, the presence of an air-filled cave chamber above the currently known levels of the cave can explain the depleted concentrations.

Comparing Dripl (smallest vertical distance to the surface) and Drip3 (largest vertical distance). Drip3 has significantly elevated sulfate, calcium, and magnesium content, but less nitrate. Despite the higher hardness, no precipitation is observable at the dripping site, which is probably caused by the elevated $\mathrm{CO}_{2}$ level in the $\mathrm{KH}$. The elevated sulfate, magnesium and calcium levels indicate longer residence time in the pyrite containing marl layers above the level of the cave. The higher sodium content can also be the result of an ion exchange process between the alkaline earth metal ions and the sodium-containing clay minerals in the Buda Marl.

The Drip4 sampling site displays concentrations that are smaller than all other drip sites. The yield of dripwater at this site is high and the yield is observed to increase immediately after rain, so we conclude that this site has direct connection to the near surface.

For the water filling the conduits, several sites were sampled. In two of the open water sites (Boltív spring and ML) the results were not reproducible based on the intermixing of the two springs feeding the lake, proving to be an

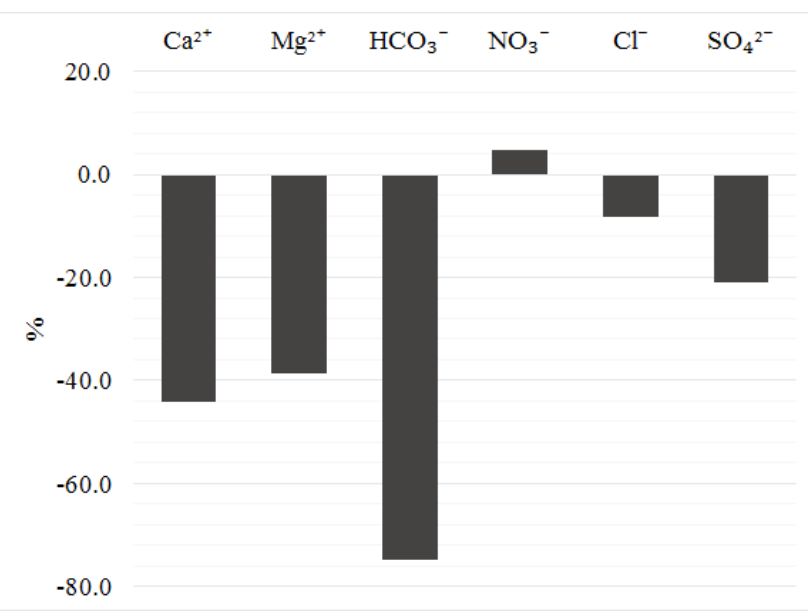

Fig. 7 Percentage difference of ions concentration of points Drip1 and Drip2 inconsistent sampling point. From Bergmann et al. [20] and Erőss et al. [16] studies, only the results from the KH (A32) can be compared, while in the case of the Farkas et al. [17], two more sampling points (A44 and C37 correspond to 1 and 2) are identical to the present ones. Comparison of the data obtained at the A32 point can be seen in Fig. 6 (d). The most striking feature of the comparison is the continued decrease of the sulfate concentration from 2010, which reverses the increasing trend beginning in 1938 that could be concluded from the literature data compiled in the Farkas et al. [17]. Although, this decrease could be based on the fact that there is a reduced contribution of thermal water at this point, no parallel temperature change was detected. Other investigated ions show only minor changes.

C37 sampling point possesses the farthest properties from the A32 according to the cluster analysis due to its low temperature and conductivity but slightly higher nitrate content. Surprisingly, this very different water shows a similar behavior: the most significant change is the decrease of sulfate concentration.

The A44 sampling point also displays lower sulfate concentration compared to the 2015 values, however another notable change, the decrease of hydrogen carbonate appears. The values obtained from 2016 show remarkable stability, we attribute the large difference to the fact that the 2015 study moved the actual sampling from the A44 point to the A36, since this point possessed similar chemistry but closer to the entrance. However, the small distance to the KH and the shallower depth ( $12 \mathrm{~m}$ vs. $21 \mathrm{~m}$ of the A44) may also involve the easier mixing of the warmer water from $\mathrm{KH}$ (the mixing zone is between 9 and $11 \mathrm{~m}$ depth).

We can conclude that the only significant $(>10 \%)$ difference between the Farkas et al. [17] study and our 20162019 sampling campaign is the decrease of the sulfate concentration. Since the sulfate in the lukewarm waters of the BTK is supposed to originate from the Kiscell and Tard clay formations [23], we can attribute the difference to a decreased contact time of the cave water in these layers.

\subsubsection{Yearly and seasonal variations}

An earlier attempt to observe seasonality in the conductivity and level of the Malom Lake found no correlation with rainfall events or even integrated precipitation [24].

The four years span of our research allowed us to look for both yearly and seasonal variations in the water chemistry data. Plotting the coefficient of variation (CV) of a quantity of interest can show us the relative magnitude of change, highlighting the ones that show significant changes. Averaging for certain intervals then calculating 
the $\mathrm{CV}$ of the averages eliminates the fluctuations within the intervals and highlights the differences between the individual periods.

The CV values corresponding to the entire 4 years span of the ion concentration data at the different sampling points are plotted on Fig. 8. Hydrogen carbonate ions were excluded from this analysis, because the analysis time after sample collection was not uniform during the sampling period, corrupting the $\mathrm{CV}$ values for this ion. Sulfate concentrations were excluded from the four years trend since we have only data from two years (2016 and 2017). Since the sampling of the Drip2 site began only in 2018, the four years trend was also not analyzed for this site.

Comparing the CVs of the dripwaters and the conduit waters we can observe that the dripwaters display significantly higher variation. Changes in the surface conditions like the temperature or precipitation influence the dripwaters more readily, since the long infiltration time of waters filling the conduits of hypogenic caves dampens the effects of seasonal fluctuations or even year-to-year differences.
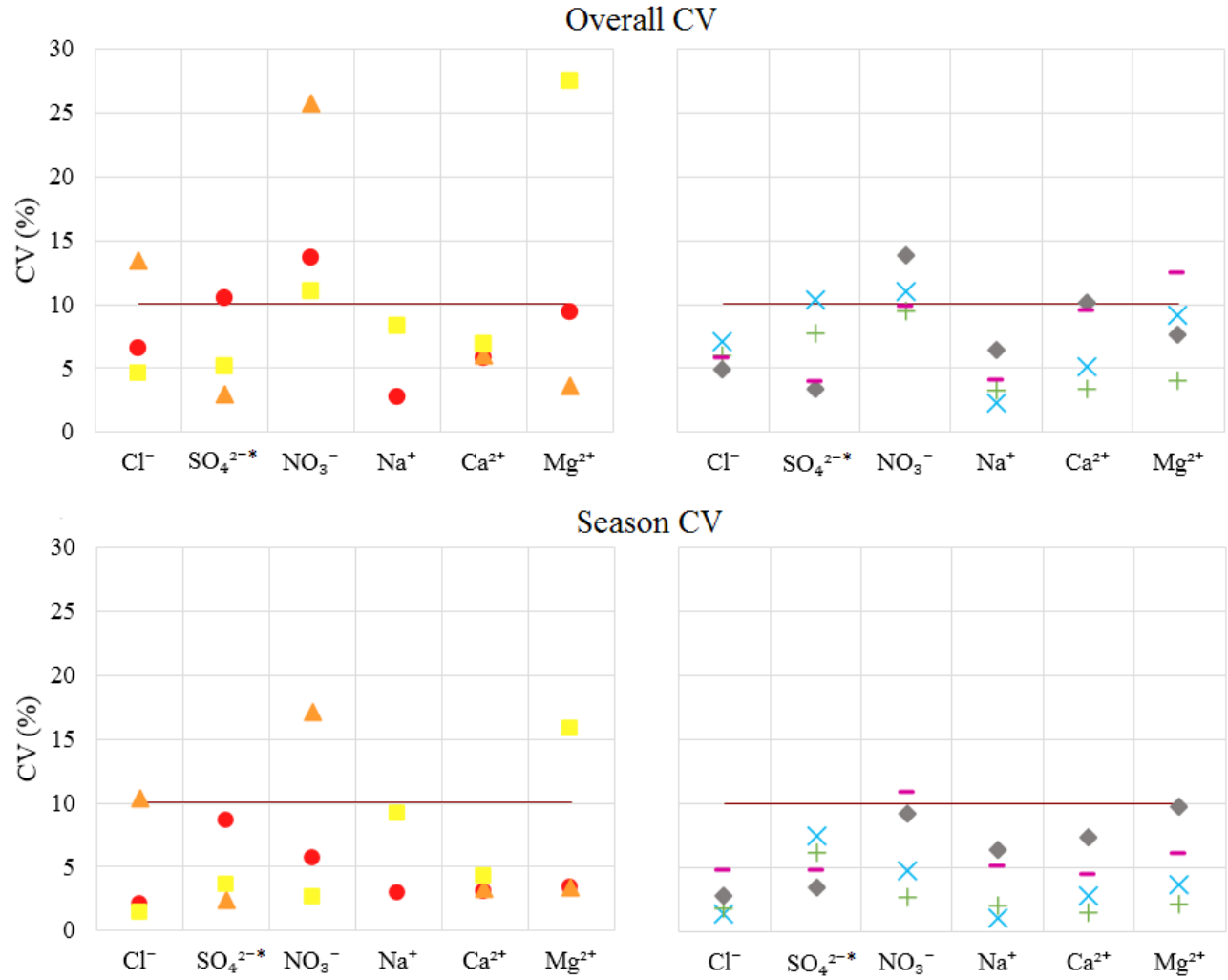

Season CV
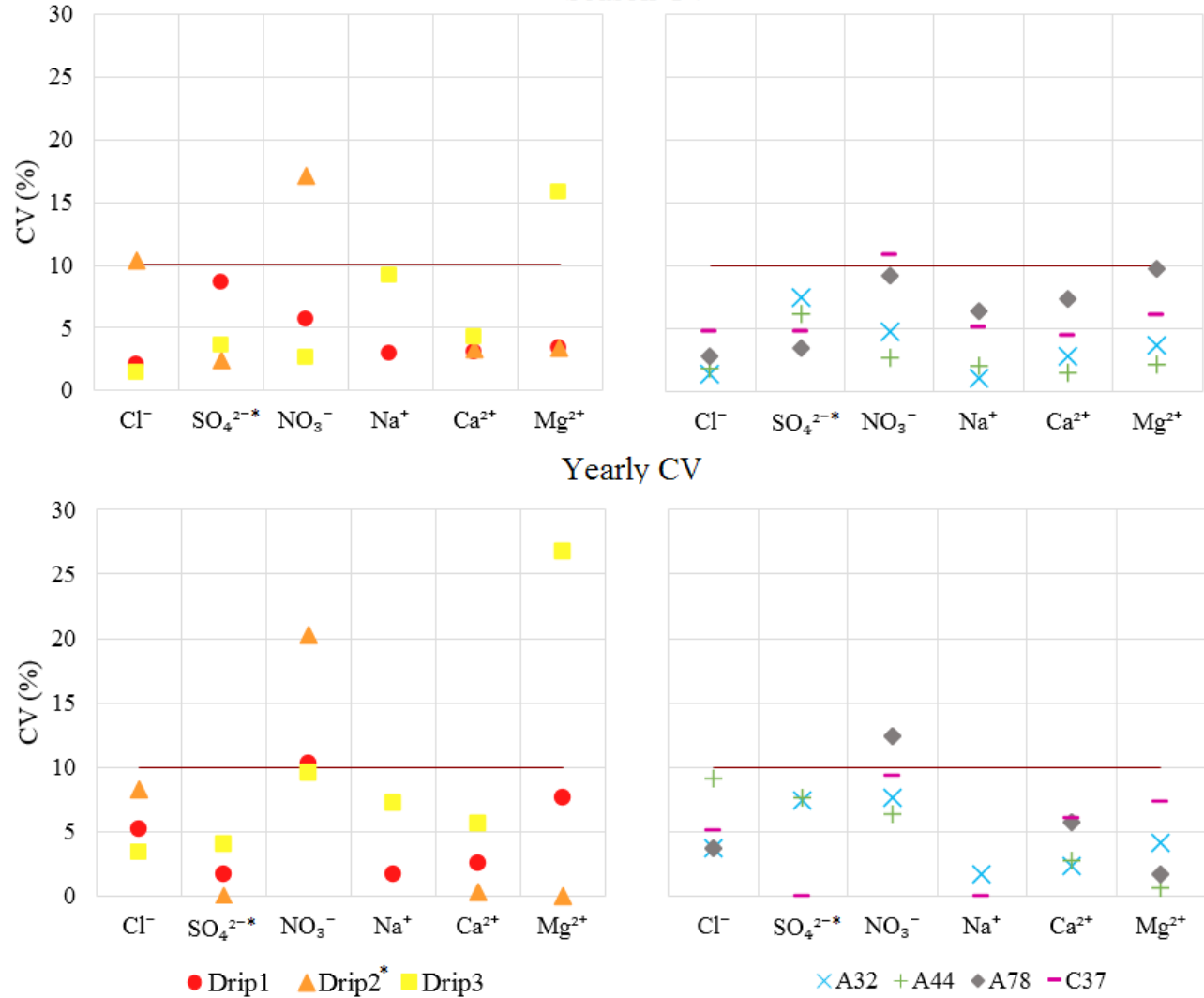

Yearly CV

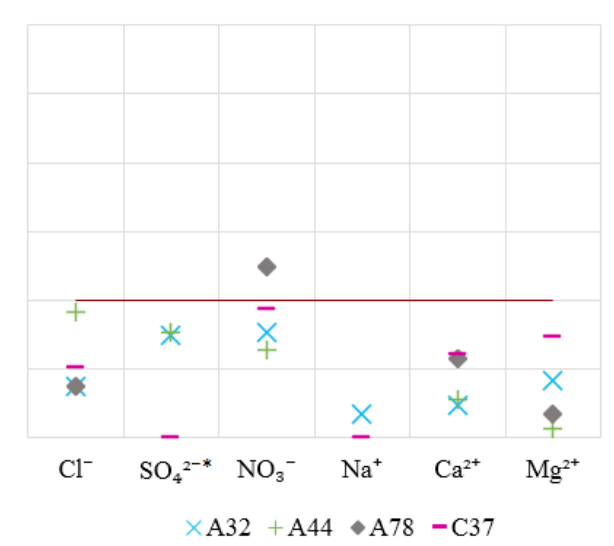

Fig. 8 Seasonal, yearly, and overall CV. Seasonal refers to the seasons of the year (March-May; June-August; September-November and DecemberFebruary) and yearly refers to the variation on the 4-year data. Overall is based on the entire data. *Data from point Drip2 are from $2018-2019$ and data on $\mathrm{SO}_{4}{ }^{2-}$ are from 2016-2017 
In case of the dripwaters, we can see that the Drip1 site (although this is the sampling site closest to the surface) shows considerably less variation than the other two sites. The highest overall CV corresponds to the chloride and nitrate ions at the Drip2 and magnesium ions at the Drip3 sites. Only in the case of the nitrate rises the CV above the $10 \%$ limit at all three dripwater sampling sites. Forming the seasonal averages decreased the CV somewhat, but in case of chloride and nitrate at the Drip2, and magnesium at the Drip3 site the coefficient of variation remained above the $10 \%$ limit. The variation of these three ions can be contributed to anthropogenic origin (e.g., sewage water or fertilizers in case of the nitrate, and de-icing agents in case of the chloride and magnesium ions) thus the seasonal variation should mirror the seasonal usage of these ions. Plotting the seasonal averages (Fig. 9) for the concentrations of nitrate ions at the Drip2 site shows the highest values in the spring, decreasing monotonously in the summer and autumn seasons, reaching the lowest concentrations in the winter. This type of behavior is consistent with the usual utilization of nitrogen fertilizers in the springtime; thus, the origin of nitrate can be attributed to agricultural activities. Since the cave is under a heavily built-up city area and the use of fertilizers in gardens and city parks is limited, the infiltration site of these dripwaters is possibly outside the city limits, several kilometers away from the cave. Chloride ions at the Drip2 site also show a decrease from spring to autumn, however the winter months bring an increase, which agrees with the winter load of de-icing agents used on the city streets. Since indications about the origin of the nitrate and chloride ions are conflicting, we can conclude that the Drip2 site collects infiltrating waters from different areas.

The seasonal averaging reduced the $\mathrm{CV}$ of the nitrate ions at the Drip3 site below the $10 \%$ limit, while that of the $\mathrm{Mg}$ ions remained significant. Since the chloride ions show no seasonality, we cannot contribute the variation of the Mg ions to modern de-icing agents. Although the high variation of the magnesium content could be explained by the changing residence time of the infiltrating waters, the lack of seasonality of the other ion concentrations refutes this explanation. Again, the dissimilar behavior of the individual ions indicates that the magnesium ions reach the cave at a different route.

Thus, although only a few drip sites are found in the Molnár János cave, each of the drip sites collects infiltrating waters from different sources and infiltration routes, ranging from within the city to outside of the city limits. This is consistent with an impermeable layer of clay above cave that channels the few fissures penetrating the aquiclude layer.

Contrary to the dripwaters, conduit waters show CVs higher than $10 \%$ only in a few cases, never exceeding $14 \%$ vs the $27 \%$ maximum value of the dripwaters (see Table 3 ). High CVs are only found at two of the regularly sampled sites, the $\mathrm{C} 37$ and the $\mathrm{A} 78$ points. Although these sites are quite distant to each other in terms of cave passages, the net distance is much closer (see the map on Fig. 3). This allows the conclusion that a common fissure system conducts the cooler waters there. The ions showing high variation are the nitrate and the magnesium ions, two of the ions that displayed high variation in case of the dripwaters. The low variation in the chloride can be contributed to a different, natural source: studies from Mádl-Szőnyi et al. [4] and Eröss et al. [5] show a conceptual system that demonstrates how $\mathrm{Na}^{+}$and $\mathrm{Cl}^{-}$comes from the plane side of the Danube (Pest side) and rises with the thermal waters. Both seasonal and yearly averaging decreased the $\mathrm{CV}$ of nitrate at $\mathrm{C} 37$ and $\mathrm{A} 78$, however both remain above or just below the $10 \%$ limit. The nitrate concentrations at $\mathrm{C} 37$ show a very similar behavior to the nitrate at the Drip2 site: highest in the spring and lowest in the winter, that might hint at the common origin of the contaminant ion. The much lower concentration at the $\mathrm{C} 37$ site is the result of the dilution of the dripwater.

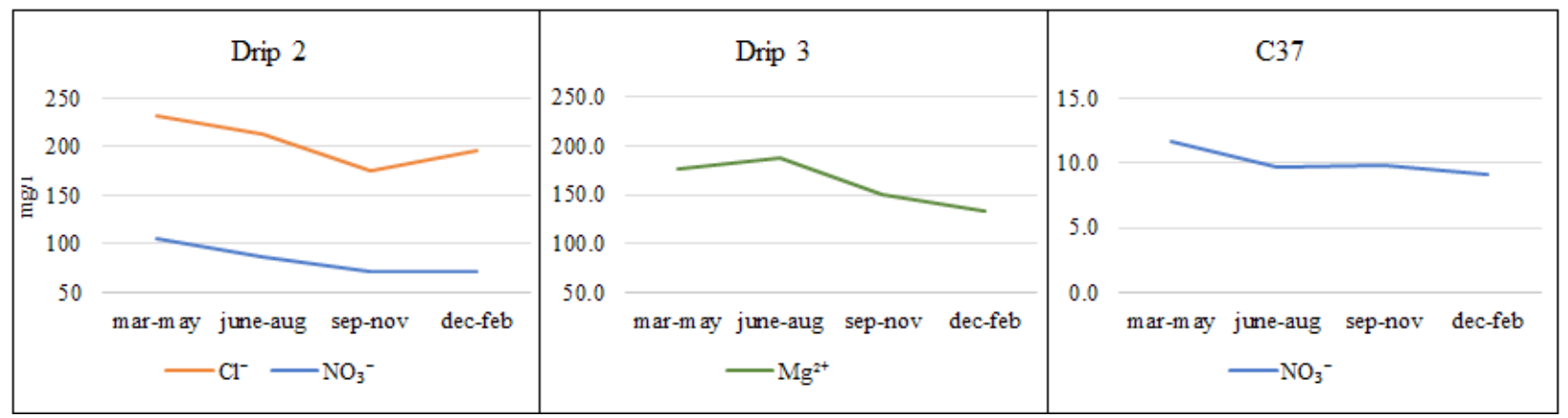

Fig. 9 Seasonal changes of outstanding components 


\section{Conclusions}

The extensive sampling of the Molnár János cave brought important observations regarding the spatial distribution and seasonality of the water chemistry and the exposure of the cave to the effect of the city above. The spatial variability of the temperature and water chemistry was mapped.

The characteristics of the sampling points, based on the chemical composition, were separated into groups using cluster analysis. Dripwaters and conduit waters show the largest separation, while conduit waters were further divided into three groups.

Near the KH two water types were identified: a warmer, occupying the upper layer, and a lower temperature one found deeper than $9 \mathrm{~m}$ with a sharp thermocline separating the two. The ionic concentrations also show a sharp change parallel with the temperature. In the remote parts of the cave the warmer component cannot be found, the temperature shows only a gradual change with depth, without measurable concentration changes. Both temperature and concentration anomalies were found near the endpoints of the "A" and " $\mathrm{C}$ " passages. Despite the distance from the entrance and the surface the colder temperature and the higher nitrate concentrations marked these sites as entry points of pollution from the surface. Although generally the ion concentrations in the water filling the cave conduits show only minor changes in time, at the end point of the $\mathrm{C}$ passage seasonality was observed in the nitrate concentrations.

\section{References}

[1] Erőss, A., Poros, Z., Madl-Szőnyi, J., Mindszenty, A., Molnár, F., Ronchi, P., Csoma, A. "Role of Karstic and Basinal Fluids in Porosity Evolution in the Buda Hills, Hungary", presented at International Convention and Exhibition, Milan, Italy, Oct., 23-26, 2011.

[2] Erőss, A., Mádl-Szőnyi, J., Surbeck, H., Horváth, Á., Goldscheider, N., Csoma, A. É. "Radionuclides as natural tracers for the characterization of fluids in regional discharge areas, Buda Thermal Karst, Hungary", Journal of Hydrology, 426-427, pp. 124-137, 2012.

https://doi.org/10.1016/j.jhydrol.2012.01.031

[3] Leél-Össy, S. "Caves of the Buda Thermal Karst", In: Klimchouk, A., Palmer, A. N., De Waele, J., Auler, A. S., Audra, P. (eds.) Hypogene Karst Regions and Caves of the World, Springer, Cham, 2017, pp. 279-297.

https://doi.org/10.1007/978-3-319-53348-3_18

[4] Mádl-Szőnyi, J., Erőss, A., Tóth, Á. "Fluid Flow Systems and Hypogene Karst of the Transdanubian Range, Hungary - With Special Emphasis on Buda Thermal Karst", In: Klimchouk, A., Palmer, A. N., Waele, J. D., Auler, A. S., Audra, P. (eds.) Hypogene Karst Regions and Caves of the World, Springer, Cham, 2017, pp. 267-278. https://doi.org/10.1007/978-3-319-53348-3 17
The huge amount of drinking quality water stored in the cave, as mentioned in Farkas et al. [17], makes the assessment of the vulnerability to anthropogenic pollution very important.

During the sampling season several air-filled chambers were discovered, however no penetration of dripwater was observed beyond the immediate vicinity of the $\mathrm{KH}$. Thus - apart from the endpoints of the $\mathrm{A}$ and $\mathrm{C}$ passages no surface contamination was found to enter the new parts of the cave. The known dripwater entry points carry a high concentration of pollution indicator ions (nitrate, chloride) into the cave, and sulfate ions that hint at a long residence time of the dripwaters in the pyrite-containing marl layers. Dripwaters show high seasonality indicating a relatively close connection to the surface. The individual ions display different variations in time, the fissures carrying the dripwaters into the cave collect waters from several different sources, ranging from the city streets and sewers to the cultivated lands surrounding Budapest.

\section{Acknowledgment}

The research reported in this paper was supported by the BME water Sciences \& Disaster Prevention TK2020 IE grant of NKFIH Hungary (BME IE-VIZ TKP2020). Also, we would like to thank the MJCAVE operation, the BBTT cave diving group and Wessling laboratory for all the support during this study.

[5] Erőss, A., Mádl-Szőnyi, J., Csoma, A. É. "Characteristics of discharge at Rose and Gellért Hills, Budapest, Hungary", Central European Geology, 51(3), pp. 267-281, 2008. http://doi.org/10.1556/CEuGeol.51.2008.3.8

[6] Poros, Z., Mindszenty, A., Molnár, F., Pironon, J., Győri, O., Ronch, P., Szekeres, Z. "Imprints of hydrocarbon-bearing basinal fluids on a karst system: mineralogical and fluid inclusion studies from the Buda Hills, Hungary", International Journal of Earth Sciences, 101, pp. 429-452, 2012. https://doi.org/10.1007/s00531-011-0677-8

[7] Erőss, A., Madl-Szőnyi, J., Csoma, A. "Characterization of Fluids and Their Products in a Recent, Fault-Related Hydrothermal System, Case Study from the Buda Thermal Karst, Hungary", presented at AAPG International Convention and Exhibition, Milan, Italy, Oct., 23-26, 2011.

[8] Waele, J. D., Gutíerrez, F., Parise, M., Plan, L. "Geomorphology and natural hazards in karst areas: A review", Geomorphology, 134(1-2), pp. 1-8, 2011.

https://doi.org/10.1016/j.geomorph.2011.08.001 
[9] Albert, G., Virág, M., Erőss, A. "Karst porosity estimations from archive cave surveys - studies in the Buda Thermal Karst System (Hungary)", International Journal of Speleology, 44(2), pp. 151-165, 2015.

https://doi.org/10.5038/1827-806X.44.2.5

[10] Goldscheider, N., Mádl-Szőnyi, J., Erőss, A., Schill, E. "Review: Thermal water resources in carbonate rock aquifers", Hydrogeology Journal, 18(6), pp. 1303-1318, 2010. https://doi.org/10.1007/s10040-010-0611-3

[11] Szanyi, G., Surányi, G., Leél-Össy, S. "Cave development and Quaternary uplift history in the Central Pannonian Basin derived from speleothem ages", Quaternary Geochronology, 14, pp. $18-25,2012$. https://doi.org/10.1016/j.quageo.2012.09.001

[12] Erhardt, I., Ötvös, V., Erőss, A., Czauner, B., Simon, S., Mádl-Szőnyi, J. "Hydraulic evaluation of the hypogenic karst area in Budapest (Hungary)", Hydrogeology Journal, 25(6), pp. 1871-1891, 2017. https://doi.org/10.1007/s10040-017-1591-3

[13] Molnár, J. "A Lukácsfürdő Budán, természettudományi tekintetben" (The Lukácsfürdő in Buda, in terms of natural sciences), A Királyi Magyar Természettudományi Társulat Évkönyvei 1857-1859, 4, pp. 142-176, 1859. [online] Available at: http://real-j.mtak.hu/id/ eprint/6826 [Accessed: 05 December 2020] (in Hungarian)

[14] FTSK Delfin Könnyübúvár Szakosztály Vízalatti Kutatócsoport "Kutatási jelentés 1978" (Research report 1978), [pdf] FTSK Delfin Könnyűbúvár Szakosztály, Budapest, Hungary, Available at: https://termeszetvedelem.hu/_user/browser/ File/barlangkutat\%C3\%A1si\%20jelent\%C3\%A 9sek/1978/ delfin_1978.pdf [Accessed: 05 December 2020] (in Hungarian)

[15] Sóregi, I. "Az urbanizáció hatása a Budai Termálkarsztra" (The impact of urbanization on the Buda Thermal Karst), BSc Thesis, Szent István Egyetem, 2019. [online] Available at: http://termeszetvedelem.hu/_user/browser/File/barlangkutat $\%$ C3\%A1si\%20jelent\%C3\%A9sek/2009/soregi_ildiko_2009.pdf [Accessed: 26 November 2020] (in Hungarian)

[16] Erőss, A., Mádl-Szónyi, J., Csoma, A. É. "Hypogenic karst development in a hydrogeological context, Buda Thermal Karst, Budapest, Hungary", In: Maloszewski, P., Witczak, S., Malina, G. (eds.) Groundwater Quality Sustainability, CRC Press, London, UK, 2012, pp. 119-133. https://doi.org/10.1201/b12715-15
[17] Farkas, D., Hajnal, G., Szieberth, D., Rehák, A. "A Molnár János-barlang térségének hidrológiai vizsgálata" (Hydrological examination of the Molnár János cave), In: MérnökgeológiaKözetmechanika 2015, Budapest, Hungary, 2015, pp. 61-74. [online] Available at: http://docplayer.hu/108888729-A-molnarjanos-barlang-tersegenek-hidrologiai-vizsgalata.html [Accessed: 15 November 2020] (in Hungarian)

[18] Alföldi, L. "A layers thermal-water twin flow system", Journal of Hydrology, 56(1-2), pp. 99-105, 1982. https://doi.org/10.1016/0022-1694(82)90059-2

[19] Anda, D., Krett, G., Makk, J., Márialigeti, K., Mádl-Szőnyi, J., Borsodi, A. K. "Comparison of bacterial and archaeal communities from different habitats of the hypogenic Molnár János Cave of the Buda Thermal Karst System (Hungary)", Journal of Cave and Karst Studies, 79(2), pp. 113-121, 2017. https://doi.org/10.4311/2015MB0134

[20] Bergmann, C., Leél-Őssy, S., Fehér, K., Fórizs, I. "Vízvizsgálatok a Molnár János-Barlangban" (Water tests in the János Molnár Cave), In: Karsztfejlődés XVI., Szombathely, Hungary, 2011, pp. 223-245. [online] Available at: http://epa.oszk.hu/03100/03192/00016/pdf/ EPA03192_karsztfejlodes_2011_16_223-245.pdf [Accessed: 19 July 2021] (in Hungarian)

[21] Hungarian National Standards "MSZ 448-44 Drinking water. Bacteriological testing", Magyar Szabványügyi Testület, Budapest, Hungary, 1990.

[22] Ragno, G., De Luca, M., Ioele, G. "An application of cluster analysis and multivariate classification methods to spring water monitoring data", Microchemical Journal, 87(2), pp. 119-127, 2007. https://doi.org/10.1016/j.microc.2007.06.003

[23] Molnár, F., Kiss, G. B., Mádl-Szőnyi, J., Erőss, A., Mindszenty, A. "Field Course on Fluid-Rock Interaction in Shallow Hydrothermal Systems - Program and field guide", [pdf] József and Erzsébet Tóth Endowed Hydrogeology Chair Foundation, Hungary, Available at: http:/enerag.elte.hu/wp-content/uploads/2019/06/ENeRAG_fieldcourse-program-and-field-guide.pdf [Accessed: 28 June 2021]

[24] Bodor, P., Erőss, A., Mádl-Szőnyi, J., Kovács, J. "A csapadék hatása a rózsadombi források utánpótlódási és megcsapolódási területén" (The effect of precipitation on the replenishment and drainage of the Rose Hill springs), [pdf] Földtani Közlöny, 145(4), pp. 385-396, 2015. Available at: https://epa.oszk.hu/01600/01635/00374/pdf/ EPA01635_foldtani_kozlony_2015_145_4_385-396.pdf [Accessed: 19 July 2021] (in Hungarian) 